\title{
INKONSISTENSI PRINSIP TIME VALUE OF MONEY DALAM OPERASIONAL TRANSAKSI KEUANGAN SYARIAH DAN SOLUSINYA
}

\author{
Siti Mujibatun \\ UIN Walisongo Semarang \\ Siti.mujib@yahoo.com
}

\begin{abstract}
The concept of Time V alue of Money in the LKS is not accepted because of riba, but in practically mainly on small investors to invest, will face a big problem if it rejects the principle of Time Value of Money, whenever any country will have inflation. will be injustice when Islamic banking do not give a rate of return to the investor. The research is a qualitative, primary data sources and data collection consisted of a document. The Brochure of Product Financing Transactions in LKS, b). Fatwa DSN-MUI 2000, c). CD-ROM File Maushu'ah al-Hadith al-Sharif al-Tis'ah 1997 Edition II, d). The Books related to the concept of Time Value of Money, e). SOP (Standard Operational Product) financing and acounting system. Secondary data consists of various books related to the concept of Time Value of Money both modern and classical fiqh books and Research results related to this research problem. This research analyzes the discriftive approach, with results as follows: 1. Time Value of Money in the LKS is not acceptable, because the increase in the Time V alue of Money earned should be of real business, not because of the debt contract / qardh 2. Time V alue of Money by economic concepts Hadis Muhammad saw among other things contained in the contract of salam/ indent, $B B A$ and 'disconto, araya and provision for debt payments 3. the occurrence of in-consistency between ideology Time $V$ alue of Money with praxis in LKS due in addition to not paying attention to the business logic of the Prophet, helplessness in operating system usage still based on the operating system Conventional Financial Institutions (LKK).
\end{abstract}

Keywords: In-Consistency; Time V alue of Money; LKS.

\section{Pendahuluan}

Sistem keuangan syariah memberikan preferensi pada proyek-proyek dengan tingkat relatif tinggi ketika peluang investasi tersedia di berbagai tingkatan tanpa memandang apakah investasi tersebut risk averse atau risk 
seekers sejauh risiko yang akan diperkirakan dapat diganti dengan laju keuntungan yang diharapkan. Dengan ketiadaan aset bunga dan ancaman erosi inflasi dan pajak idle fund, maka peluang secara optimal yang dapat dilakukan adalah menginvestasikan dananya setelah dikurangi transaksi dan berjaga-jaga pada tingkat rate return yang sesuai. ${ }^{1}$

Komponen rate of return yang mencerminkan ekspektasi masyarakat akan investasi yang dilakukannya merupakan salah satu alternatif yang mampu menggantikan bunga. Dengan rate of return pelaku bisnis dan investor (pemilik modal) memiliki peluang untuk memaksimalkan usaha mereka demi keuntungan bersama.

Ekspektasi return berbeda dengan suku bunga yang selalu dijustifikasikan dengan time value of money, justru dikaitkan dengan economic value of money atau nilai ekonomi dari uang. Artinya bahwa uang akan memiliki nilai jika masuk ke dalam perekonomian dan menghasilkan (memiliki value added). Menurut para pakar perbankan syariah bahwa faktor yang menentukan nilai waktu adalah bagaimana seseorang memanfaatkan waktu itu, semakin efektif dan efisien maka akan semakin tinggi nilai waktunya. Dengan pemanfaatan waktu sebaik-baiknya untuk bekerja dan berusaha akan menghasilkan pendapatan yang dapat dinilai dengan uang.

Hal ini akan bertentangan dengan konsep time value of money yang secara tidak proporsional mempertimbangkan probabilitas terjadinya deflasi selain adanya inflasi atau kemungkinan adanya return negatif dan juga return positif. Pada kenyataannya, ketidakpastian (uncertainty) selalu terjadi dan menjadi sangat tidak adil jika hanya menuntut adanya kepastian sebagaimana yang berlaku dalam ekonomi konvensional melalui konsep time value of moneynya. Oleh karena itu pemodal dalam ekonomi syariah tidak berhak meminta rate of return yang nilainya tetap. Prinsip ini berargumen bahwa tidak seorang pun berhak mendapatkan tambahan dari pokok yang ditanamkannya tanpa keikutsertaan dalam menanggung risiko, sebagaimana hadis lahū ghunmubu wa'alaibi ghurmubu (dia berhak memperoleh manfaat tetapi dia juga harus menanggung risiko) (HR. Ibnu Majah).

${ }^{1}$ Masyhuri dkk, Teori Ekonomi dalam Islam, Yogyakarta: Kreasi Wacana, 2005, hlm. 111. 
Secara konsep, argumen tersebut logis dan rasional, tetapi dalam tataran praktis terutama pada pemodal kecil yang melakukan saving dananya di perbankan semata-mata sebagai simpanan dan berjaga-jaga dan bukan murni untuk investasi, akan menghadapi masalah besar ketika mengabaikan prinsip time value of money, karena suatu saat negara mana pun di dunia akan mengalami inflasi meskipun kurang dari 0,1 \%, sehingga dana simpanan masyarakat yang dititipkan di lembaga keuangan syariah terutama perbankan akan terjadi ketidakadilan manakala bank syariah bersikukuh untuk tidak memberikan rate of return yang nilainya tetap terhadap investornya ${ }^{2}$, kecuali bentuk investasinya harus berdasarkan akad musyärakah bukan mudhärabah, sehingga kesan bank syariah adalah bank berdasarkan hanya pada prinsip LPS atau bagi hasil tanpa memperhatikan produk lain akan semakin sirna.

Berdasarkan data normatif yang dipraktikkan oleh Rasulullah saat itu, pada prinsipnya ekonomi syariah mengakui prinsip time value of money. Hal ini terbukti antara lain:

Pertama, ketika Rasulullah saw memerintahkan pengusiran orang-orang Yahudi (Bani Nadhir) dari Khaibar akibat penghianatan mereka maka ada di antara orang-orangYahudi yang mengadu kepada Rasulullah saw bahwa banyak pinjaman mereka yang belum jatuh temponya. Rasululllah saw menjawab supaya diberi discount atau rabat untuk menerima pembayaran sebelum waktunya. ${ }^{3}$

Berdasarkan riwayat tersebut discount dapat diberikan untuk menagih utang sebelum waktunya, hukum analogi discount harga dapat juga diberikan untuk pembayaran di muka dengan penyerahan barang kemudian. Sedangkan jual beli dengan pembayaran di muka dengan penyerahan kemudian (jual beli salam/indent dan dengan memberi discount harga hukumnya boleh (jäiz bi alijmā).

2 Berdasarkan hasil penelitian yang dilakukan Syed Nawab Haedar Naqvi seorang pakar ekonomi Islam Pakistan berdasarkan tingkat pengembalian deposit produk LPS dan non-LPS, ternyata pemodal kecil LPS lebih dirugikan dibanding dengan deposit bunga. Inilah yang menurutnya dengan produk LPS telah terjadi ketidakadilan dalam transaksi keuangan syariah (Syed Nawab Haedar Naqvi, Menggagas Ilmu Ekonomi Islam, terj. M. Saiful Anam \& Muhammad Ufuqul Mubin, Yogyakarta: Pustaka Pelajar, 2005, hlm. 206-207.

3 Ibn Rusyd, Bidāyah al-Mujtahid, Juz 2, Beirut: Dār al-Fikr, t.t., hlm. 108. 
Terdapat persoalan lain dalam jual beli salam yaitu jual beli stamar (buah-buahan) bisa dipahami secara umum meliputi semua hasil komoditas pertanian, lebih jauh secara hukum progresif dan modern meliputi perdagangan logam, metal dan komoditas lain termasuk modal.

Kedua, jual beli dengan sistem bayar angsur (bai bi tsaman äjil). Ba $i \mathrm{Bi}$ tsaman Ajil (BBA) dalam praktik bisnis keuangan syariah secara sederhana mirip dengan jual beli (Jawa: mindreng) yakni membeli barang dengan cara pembayaran angsur-kredit, dan menurut pernyataan riwayat bentuk jual beli tersebut mengandung berkah. Meskipun pembayaran dalam BBA secara angsur, tetapi logika ekonomi akan mendesain harga lebih tinggi di atas harga pasar. Secara tidak langsung hadis tersebut mentolerir adanya prinsip time value of money, karena tinggi rendahnya harga barang diperhitungkan dengan waktu pembayaran. Dan masih ada lagi dasar normatif praktik Rasulullah saw dalam mempertimbangan prinsip time value of money yang jarang dibahas dalam kajian ilmu ekonomi Islam.

Beberapa contoh di atas akan inkonsistensi antara konsep normatif dengan apa yang selama ini dipraktikkan dalam sistem bisnis keuangan syariah terkait dengan prinsip time value of money. Untuk itu penelitian ini akan mengeksplorasi data normatif tentang prinsip time value of money yang terdapat dalam dokumen riwayat yang dipraktikkan Rasulullah saw serta menjelaskan secara proporsional dengan yang berlaku di bisnis keuangan syariah, untuk menghindari ambiguitas pemahaman di kalangan stakeholder tentang sistem bisnis keuangan syariah yang sesungguhnya memiliki berbagai karakter sesuai dengan kebutuhan umat.

Penelitian ini bersifat deskriptif kualitatif dengan sumber data dari perpustakaan (library research). Metode kualitatif dipilih dengan beberapa alasan. Pertama, lebih mudah menyesuaikan data apabila berhadapan dengan informasi ganda. Kedua, metode ini menyajikan secara langsung hakikat peneliti dengan data yang diteliti yaitu dokumen. Dan ketiga, lebih fleksibel dalam melihat data yang akan diteliti.

Adapun tahap-tahap penelitian yang akan dilakukan meliputi. Pertama, memetakan penentuan sampel tentang hadis transaksi yang terindikasikan 
adanya prinsip time value of money serta menjelaskan secara tegas prinsip time value of money yang dikenal dalam konsep ekonomi Islam. Kedua, proses pencatatan dan editing serta analisis data. Ketiga, penyajian data yang dimulai dari deskripsi penemuan, kemudian deskripsi hasil analisis data dengan memberikan penjelasan berdasarkan pada konsep dan kerangka teori. Keempat, pemeriksaan keabsahan data. Kelima, menyusun kesimpulan dan rekomendasi (jika diperlukan).

Sumber data dalam penelitian ini adalah data primer berupa dokumen yaitu: (a) Kumpulan Fatwa DSN-MUI Tahun 2000, (b) Brosur Produk LKS, (c) Brosur Produk LKK, (d) Matan hadis dan syarb-nya dalam kitab transaksi (bāb al-buyū'), (e) Kitab fiqh mazhab empat (Hanafi, Maliki, Syafi'i dan Hanbali), (f) Kitab ushul fiqh antara lain Ushul Fiqh karya Nasrun Haroen.

Pencarian sumber data penelitian ini menggunakan bantuan referensi dari File CD-ROM Mausu'ah al-Hadis al-Syarif Kutub al-Tis'ah edisi II tahun 1997, dengan obyek data mengambil fokus pada tema babts dengan sub bahasan pada dalil-dalil mengenai bab fiqh (بحث بدلالة موضوع الفقهي). Kemudian membuka judul al-buy $\bar{\prime}$ ' dengan membuka sub judul al-muwadha'at. Menurut keyakinan peneliti bahwa teks hadis dalam file tersebut merupakan kopi dari kitab asli terbitan Dār al-Fikr Beirut.

Analisis data penelitian ini menggunakan teknik deskriptif dan content analysis, yaitu dengan menjelaskan prinsip time value of money versi pakar ekonomi syariah serta memperhadapkan dengan teks hadis tentang transaksi yang terindikasi prinsip time value of money sehingga dapat diperoleh solusi aplikatif secara proporsional antara prinsip yang dikembangkan dengan fakta dokumen dari praktik Rasulullah saw. Dengan begitu, akan diperoleh informasi yang membingungkan serta mengandung ambiguitas dalam kerangka pengamalan muamalah sehari-hari.

Di sisi lain analisis isi hadis yang mengandung muatan time value of money akan memberikan informasi berimbang terhadap operasional transaksi keuangan-perbankan (syariah), sehingga diperoleh gambaran karakteristik hasil ijtihad kedua versi (time value of money versi praktik Rasulullah saw dan pakar ekonomi Islam) secara koresponden dan konsisten. Materi yang 
diasumsikan dan diasosisikan dari dua versi tersebut dimungkinkan bisa aplikatif meskipun pada akhirnya tetap saja bersifat spekulatif ijtihadi bahkan berbeda satu sama lain.

Content analysis dipakai dalam menjelaskan materi hadis dengan pendekatan hukum (figh al-hadits), karena hadis-hadis transaksi akan dapat dipahami secara utuh jika dihadapkan pada pemahaman yang dibangun oleh para ulama fikih (fukaha) dan LKS sebagai lembaga transaksi berbasis syariah rujukannya bersumber dari berbagai pendapat ulama fikih klasik yang terdapat dalam kitab fikih muamalah.

\section{Landasan Teori}

\section{Konsep Time Value of Money}

Menurut Ja'far al-Jazzar dalam buku al-Bunük fi al-'Alam: Anwā'uhā wa Kayfa Tata'ámalu ma'ahā, bahwa time value of money adalah suatu istilah yang digunakan dalam sistem operasional bank konvensional berdasarkan keuntungan kinerjanya menggunakan standar baku bunga. Sementara bunga itu sendiri adalah nilai harga yang harus dibayar sebagai imbalan dari pemakaian uang. Atau tambahan nilai harga sebagai imbalan dari peminjaman uang berjangka. ${ }^{4}$

Berdasarkan definisi tersebut, dalam konteks ekonomi Islam bunga termasuk riba yang diharamkan. Namun, di sisi lain, sebagai sebuah bank, bank syariah juga memiliki sistem operasional dalam mengelola uang secara berjangka, sehingga kuat dugaan bahwa bank syariah terindikasi mengandung prinsip time value of money. Meskipun demikian, dalam mengelola produk lain, bank syariah juga memiliki produk yang sama sekali tidak ada kaitannya dengan bunga, misalnya pada pendapatan berupa fee dan saling berbagi dalam keuntungan dan risikonya (dalam transaksi musyārakab).

${ }^{4}$ Ja'far al-Jazzar dalam buku al-Bunüke fi al-'Alam: Anwāuhà wa Kayfa Tata 'ämalu ma'ahā, Beirut: Dar al-Nafāis, 1984, hlm. 163 


\section{Transaksi Keuangan Syariah}

Transaksi keuangan syariah dalam kajian ini adalah bentuk-bentuk bisnis uang baik melalui valas pasar-bursa saham maupun perbankan berbasis syariah. Secara definitif dalam perbankan syariah telah ditawarkan produk sebagaimana produk transaksi yang ditawarkan juga oleh bank konvensional dengan label-label transaksi sebagaimana istilah berikut:

Kegiatan Perbankan (Banking Operation)

1. Wadi ah, terdiri dari: (a) Rekening Giro, (b) Buku Tabungan (Saving Account)

2. Mudhärabah terdiri dari: (a) Tabungan Berjangka (Investment Account/deposit), (b) Usaha komenditair (Trustee).

3. Musyärakah dan musyarakah fil Irbah terdiri dari: (a) Penyertaan modal (Equity Participation), (b) Usaha patungan (Joint venture dan profit sharing/placement), (c) Modal kerja trade \& working capital financing dengan model Letter of Credit $50 \%$ deposit.

4. Salam/Indent/Sale and Future Delivery

5. BBA (penjualan dengan pembayaran kemudian atau cicilan (Deferred sale and instalment sale)

6. Ijārah terdiri dari: (a) Ijārah Muntahiya Bi Tamlik (IMBT) atau sewa beli (Hire Purchase), (b) Ijärah Mutlaqah (leasing), (c) Ijärah Khäsh (banking services), (d) Pengiriman uang/transfer, (e) Penukaran uang/Exchange, (f) Invesment/portofolio management, (g) Trustee and nominee company services.

7. Muräbahah terdiri dari: (a) Pembiayaan modal kerja/working capital financing, (b) Pembiayaan modal kerja/trade working capital financing $0 \%$ deposit.

8. Wakālah (Letter of Credit $100 \%$ Deposit)

9. Kafälah (Bank Garansi/Letter of Guarantee

Berdasarkan paparan di atas, terdapat beberapa masalah yang akan dibahas dalam tulisan ini serta solusi yang ditawarkan yaitu: (1) bagaimana prinsip time value of money dalam transaksi keuangan syariah?, (2) bagaimana prinsip time value of money menurut konsep ekonomi Rasulullah saw?, dan (3) 
Inkonsistensi Prinsip Time V alue of Money...

bagaimana solusi inkonsistensi prinsip time value of money dalam transaksi keuangan syariah?

\section{Pembahasan}

\section{Prinsip Time Value of Money dalam Transaksi Keuangan Syariah}

Menurut pemikiran pakar perbankan syariah, time value of money dipahami sebagai bentuk pemanfaatan terhadap fungsi uang semula sebagai alat bayar menjadi berubah fungsi yakni uang sebagai benda yang diperdagangkan. Sedangkan prinsip yang dipertahankan oleh pakar perbankan syariah bahwa jika uang sebagai obyek perdagangan maka hukumnya termasuk riba yang dilarang.

Konsep tersebut berdasarkan hadis larangan mempertukarkan uang emas dan sejenisnya secara sejenis dengan pelebihan dan penundaan (utang) agar tidak terjebak pada prilaku riba, sebagaimana dalam hadis berikut ini:

"Dari Sulaiman bin Ali bahwa Abu al-Mutawalli melewati orang-orang di pasar kemudian beberapa orang datang kepadanya dan saya termasuk di antara mereka. Sulaiman mengatakan, kami berkata: Kami mendatangimu untuk bertanya tentang sarf. Ia menjawab: Saya mendengar Abu Sa'id alKhudri (bahwa) orang laki-laki itu berkata kepadanya, apakah tidak ada orang antara engkau dan Rasulullah saw selain Abu Sa'id al- Khudri? Abu al-Mutawalli berkata: Tidak ada orang antara saya dengan Rasulullah saw selain dia. Ia berkata: Sesungguhnya emas dengan emas, perak dengan perak, gandum dengan gandum, jewawut dengan jewawut, kurma dengan kurma dan garam dengan garam secara sama sejenis, barang siapa menambah atau minta tambahan maka ia telah melakukan riba, orang yang mengambil dan yang memberi adalah sama." (HR. al-Nasa’i)

Berdasarkan hadis tersebut, para fukaha telah membahas secara detail mengenai pelarangan tukar menukar dua benda komoditas sejenis (uang dan makanan) secara pelebihan dan utang atau disebut riba fadhl. Riba fadhl menurut para fukaha adalah kelebihan yang terdapat pada tukar menukar antara benda-benda sejenis, seperti emas dengan emas, perak dengan perak, gandum dengan gandum, kurma dengan kurma, dan garam dengan garam. Tujuan mempertukarkan benda sejenis sebagaimana tersebut tidak akan dirasakan perlunya kecuali jika berbeda bentuk dan mutunya. Tetapi menurut 
para fukaha larangan melebihkan satu atas lainnya dalam tukar menukar dengan alasan "berbeda bentuk" yang tidak berbeda nilai atau dengan alasan "ini baik dan ini jelek", karena mungkin melihat keadaan seseorang sangat membutuhkannya, sehingga dapat membentuk mental masyarakat terbiasa melakukan demikian yang pada gilirannya menjadi masyarakat periba. Dalam kasus ini, Ibn al-Qayyim memberikan alasan dilarangnya riba fadhl untuk menjaga agar masyarakat tidak terbawa kepada riba yang berbahaya yaitu riba nasīah (riba karena utang).

Demikian juga dengan syarat adanya tunai dalam pertukaran, orang akan terhindar dari kemungkinan seseorang menuntut kelebihan pembayaran karena alasan penundaan waktu. Dengan tunai juga orang akan terikat kepada harga yang ada di pasar tanpa ada alasan penambahan karena adanya tenggang waktu, sehingga riba fadhl dilarang karena sebagai pagar agar orang tidak melakukan riba nasïah. ${ }^{5}$

Argumen para fukaha tersebut diapresiasi oleh sebagian pakar ekonomi Islam kontemporer, seperti Umar Ibrahim Vadillo dan Zaim Saidi dengan mengusung prinsip "uang konkrit" (sterilitas uang) untuk menentang riba yaitu sebuah pandangan yang didasarkan bahwa "uang tidak beranak uang" sebagai inti dari pandangan kaum Skolastik Barat dengan filsafat Aristoteles. Pandangan Aristoteles tentang uang memiliki dampak signifikan terhadap doktrin rente yang menganggap uang sebagai objek fisik memerlukan sifat-sifat fisik; uang harus dibuat dari logam, sehingga jika bukan dari logam maka tidak dianggap sebagai uang.

Pandangan kaum Skolastik Barat tentang doktrin "rente" menguatkan pandangan sebagian pakar ekonomi seperti Umar Vadillo, Zaim Saidi6 yang menganggap uang kertas termasuk benda ribawi atau uang mengandung unsur riba. Mereka berpandangan bahwa uang harus konkrit atau "uang steril", yaitu sebuah istilah yang dipakai guna menghindari riba (bunga). Pandangan tersebut kontraproduktif dan tidak realistis, karena saat ini mata

\footnotetext{
${ }^{5}$ Quraish Shihab, Riba dalam Al-Qur'an, Jakarta: Hikmah Syahid, 2006, hlm. 67.

${ }^{6}$ Ibid, hlm. 39
} 
uang yang berlaku di seluruh dunia bukan dari bahan emas tetapi sudah dirubah berupa kertas berdasarkan kesepakatan masyarakat dunia. ${ }^{7}$

Penerapan prinsip "sterilitas uang” (uang konkrit) pada ranah hukum transaksi perspektif ekonomi Islam dirumuskan dengan teori sebagai berikut: Bahwa menyewakan kuda, rumah, hukumnya boleh, sedangkan menyewakan uang tidak boleh, antara lain karena: (1) Kepemilikan uang berpindah, sehingga risiko kerusakan atau kehilangan pada benda-benda konkrit yang dipinjam juga berpindah, (2) Uang tidak bisa memburuk dan juga tidak beranak. Konsep sterilitas uang yang didasarkan pada kepemilikan atas koin konkrit dapat digambarkan seperti seorang meminjam seekor kuda yang kepemilikannya tidak berpindah kepada peminjam. Pemilik kuda wajar jika menerima imbalan berupa upah atas penggunaan miliknya (kuda).

Hal tersebut akan berbeda jika meminjamkan uang adalah suatu kontrak mutuum, yang kepemilikannya berpindah dan uang menjadi milik peminjam. Karenanya dianggap tidak adil jika peminjam harus ditarik keuntungan dari harta milik orang lain. Kontrak mutuum terbatas pada bendabenda fungible. ${ }^{8}$ Benda fungible (mäl istibläki) yaitu benda yang pemanfaatannya harus dengan cara menghabiskan benda itu sendiri misalnya bahan makanan dan uang. Mäl istibläki berlaku hukum akad qardh (utang piutang uang). Berbeda dengan māl istímäli (benda yang penggunaannya harus dengan pemanfaatan, sedang benda tersebut masih utuh). Mäl isti mäli berlaku hukum akad i'ärah dan ijärah. ${ }^{9}$

Pembedaan konsep kedua jenis benda tersebut (istibläki dan isti mäli) bersifat normative. Artinya, bahwa uang tidak dapat dijadikan sebagai objek akad pinjam meminjam (i'ärah) dan ijärah (sewa menyewa), karena pemanfaatan uang harus dengan cara menghabiskan zatnya, sedangkan obyek akad i'ärah, misalnya ketika peminjam memanfaatkan benda pinjaman, maka benda tersebut tidak akan berkurang dan masih tetap seperti semula.

${ }^{7}$ Zaim Saidi, Tidak Islaminya Bank Islam, Jakarta: Ekonesia, 2003, hlm. 54

${ }^{8}$ Ibid, hlm. 39

${ }^{9}$ Siti Mujibatun, Konsep Uang dalam Hadis, Semarang: ELsA, 2013, hlm. 480. 
Dalam konteks ini, meskipun misalnya, uang yang dipinjam akan berkurang nilainya, apalagi jika peminjaman tersebut dengan jangka waktu lama, dalam kondisi demikian, tetap saja tidak mendapatkan perhatian menurut konteks ekonomi Islam. Sebaliknya, dalam ekonomi modern tidak dikenal adanya perbedaan dua jenis benda (mäl istibläki dan mäl istìmāli) sebagaimana dikenal dalam ekonomi Islam. Menurut ekonomi modern uang adalah termasuk harta kekayaan yang memiliki nilai guna, dan benda apa pun yang memiliki nilai guna, layak dihargai dengan kompensasi termasuk di dalamnya uang atau mata uang. ${ }^{10}$

Dalil yang dipakai dalam menolak konsep time value of money dalam lembaga keuangan syariah merujuk pada atsar atau perkataan Ibn Abbas, kullu qardh jarra naf'an fabuwa al-ribä ${ }^{-11}$ (Setiap pinjaman yang menarik manfaat adalah riba). Konsep qardh inkonsisten dengan riwayat yang menyatakan bahwa Nabi saw mengembalikan pinjaman disertai kelebihan (HR. Bukhari, II: 51-52).

Di sisi lain, ketika memahami manfaat termasuk harta bernilai dan harus dihargai, tetapi pada saat uang menghasilkan manfaat, tetap saja dilarang mengambil manfaat dalam meminjamkan uang. Konsep qardh juga tidak koheren serta bersifat parsial artinya, bahwa pemahaman terhadap fungsi manfaat terlepas dari keterikatan dengan konsep māl), sebagaimana ditegaskan dalam QS. al-Nisa' [4]:24, bahwa manfaat termasuk mäl bernilai, serta tidak korespondensi artinya secara praksis, bahwa fungsi manfaat termasuk harta bernilai, tidak sejalan dengan doktrin atau konsep bahwa mengambil manfaat uang yang dipinjamkan termasuk riba yang dilarang.

\section{Time Value of Money dalam Ekonomi Konvensional}

Nilai uang sangat dipengaruhi oleh waktu. Nilai waktu dari uang merupakan suatu pertimbangan yang kritikal dalam keputusan keuangan dan investasi dalam teori konvensional. Dalam teori konvensional diakui bahwa nilai waktu uang (time value of money) menjadi bagian penting dari suatu bisnis,

\footnotetext{
${ }^{10}$ Ibid, hlm. 312

11 Al-Shan'ani, Subul al-Salām, Juz IV, Singapura: Maktabah al- 'Ilmiyah, t.t., hlm. 17.
} 
karena tujuan berbisnis adalah laba, saat ini laba dapat diperoleh dengan menerapkan konsep nilai waktu uang dalam pengelolaannya. Apalagi jika dana bisnis tersebut didapatkan dari pihak ketiga. Nilai waktu uang menjadi konsep sentral dalam teori keuangan konvensional.

Dalam pasar keuangan, waktu adalah uang (time is money), dihargai sebagai fungsi arus kas yang terhubung dengannya sebagaimana risiko yang mengelilinginya. Asalkan semuanya tetap sama, investor lebih memilih mendapatkan uangnya lebih cepat dan pengguna modal lebih memilih menunda pembayaran yang menjadi kewajibannya. Menurut Frank E. Vogel secara logika prioritas utama dalam membakukan ke dalam sebuah sistem untuk mencegah arus kas sebagai fungsi waktu yang terdapat di dalamnya. ${ }^{12}$ Analisis "arus kas yang didiskonto" ini secara sistematis mengurangi nilai arus kas ke dalam (inflows) yang diharapkan dapat diterima pada waktu tertentu pada masa mendatang. Analisis ini juga melakukan jenis penyesuaian investasi yang sama di mana pengeluaran uang dapat ditunda selama jangka waktu tertentu.

Lebih lanjut, Frank E. Vogel mengatakan bahwa penggunaan jumlah potongan tahunan ditentukan berdasarkan risiko bisnis yang berhubungan dengan investasi sekaligus cara-cara pembiayaannya. Sebagian bisnis lebih berisiko daripada yang lain. Dengan begitu, tentu membutuhkan prospek laba tahunan yang lebih tinggi daripada laba tahunan dari proyek yang memiliki risiko rendah. Semakin banyak "uang orang lain" (utang) yang digunakan, maka semakin tinggi risiko kegagalan keuangannya. Hal ini juga meningkatkan keuntungan modal minimal yang dapat diterima. Dengan demikian, maka akan menentukan tarif diskon yang lebih tinggi.

Elemen lain yang melekat pada tarif diskon adalah dugaan melemahnya daya beli karena inflasi. Teori konvensional mengakui adanya premi inflasi yang melekat pada tingkat pengembalian bebas risiko dari sebuah sekuritas. Karena semua ekspektasi pengembalian (penuh risiko) lainnya didasarkan pada tingkat bebas risiko ini. Dugaan pengembalian ini

\footnotetext{
${ }^{12}$ Frank.E, Vogel, \& Samuel L. Hayes, Hukum Kenangan Islam; Kinsey, Teori dan Praktik, Trjmh. M. Sobirin Asnawi dkk, Bandung: Nusamedia, 2007, hlm. 246
} 
disesuaikan secara otomatis dengan perkiraan tingkat inflasi. Hanya saja pada konsep ekonomi syariah tidak menerima komponen pengembalian investasi yang secara eksplisit dinamakan sebagai imbangan bagi melemahnya daya beli serta tidak mengakui adanya perbedaan antara tingkat pengembalian nominal dengan tingkat pengembalian riil. ${ }^{13}$

Berikut contoh penghitungan pembiayaan KPR BTN berbasis syariah.

Tabel 1

Angsuran Pembiayaan Syariah KPR BTN IB (Islamic Bank)

\begin{tabular}{|c|c|c|c|c|c|c|c|c|}
\hline No & $\begin{array}{c}\text { Plafond } \\
\text { (Rp) }\end{array}$ & \multicolumn{7}{|c|}{ Jangka Waktu (Bulan) } \\
\hline & & 24 & 48 & 72 & 96 & 120 & 144 & 168 \\
\hline 1 & 20.000 .000 & 952.000 & 535.000 & 673.000 & 535.000 & 452.000 & 398.000 & 363.000 \\
\hline 2 & 30.000 .000 & 1.188 .000 & 800.000 & 597.000 & 504.000 & 453.000 & 425.000 & 410.000 \\
\hline 3 & 50.000 .000 & 2.375 .000 & 899.000 & 795.000 & 640.000 & 600.000 & 507.000 & 482.000 \\
\hline 4 & 60.000 .000 & 2.849 .900 & 999.900 & 898.000 & 922.000 & 872.000 & 779.000 & 692.000 \\
\hline 5 & \multicolumn{7}{|l|}{ dan seterusnya } &
\end{tabular}

Dari tabel di atas jika dibaca secara teliti, pada pembiayaan KPR berbasis syariah secara berjangka, harga jual rumah (plafond pinjaman 20 juta), maka total pembayaran berjangka $24 \mathrm{x}$, nilai jumlah uang akan bertambah menjadi Rp. 22.848.000,-. Tambahan Rp.2.848.000,- itulah sebagai kompensasi dana pinjaman, karena peminjam telah memanfaatkan uang sebesar Rp .20.000.000,- selama jangka waktu 12 bulan. Menurut istilah konvensional kelebihan dari Rp. 20.000.000,- sebagai nilai harga uang selama 12 bulan.

\section{Prinsip Time Value of Money Menurut Konsep Ekonomi Rasulullah}

Berdasarkan data normatif yang dipraktikkan oleh Rasulullah saw saat itu, pada prinsipnya ekonomi syariah mengakui prinsip time value of money, terbukti antara lain:

${ }^{13}$ Ibid, hlm. 246. 
Inkonsistensi Prinsip Time V alue of Money...

Pertama, riwayat Ibn Abbas yang menyatakan, "Ketika Rasulullah saw memerintahkan pengusiran orang-orang Yahudi (Bani Nadhir) dari Khaibar akibat pengkhianatan mereka maka ada di antara orang-orang Yahudi yang mengadu kepada Rasulullah saw bahwa banyak pinjaman mereka yang belum jatuh temponya, Rasululllah saw menjawab supaya diberi discount atau rabat untuk menerima pembayaran sebelum waktunya."14

Berdasarkan riwayat tersebut discount dapat diberikan untuk menagih utang sebelum waktunya. Hukum analogi discount harga dapat juga diberikan untuk pembayaran di muka dengan penyerahan barang kemudian. Sedangkan jual beli dengan pembayaran di muka dengan penyerahan kemudian (jual beli salam/indent dan dengan memberi discount harga hukumnya boleh (jäiz bi alijmā).

Kedua, transaksi salam sebagaimana diriwayatkan secara masyhur dalam kitab-kitab hadis seperti hadis yang diriwayatkan oleh Imam al-Bukhari:

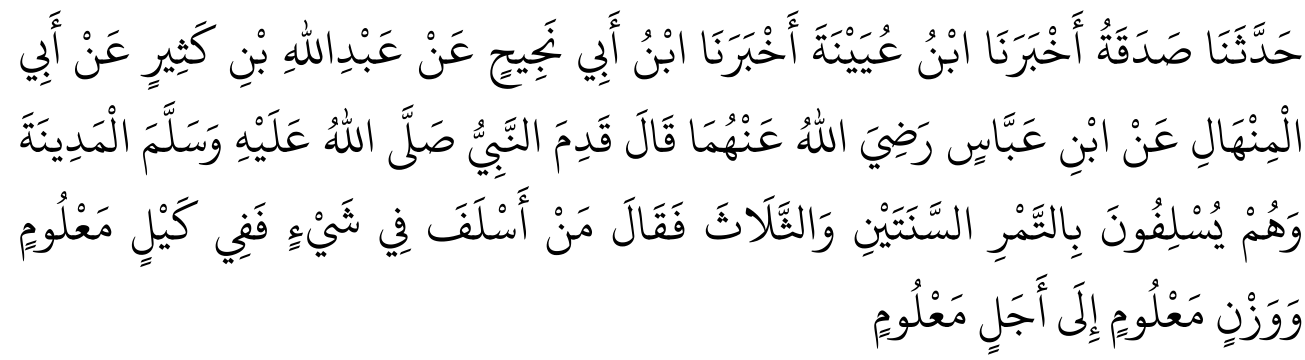

"Telah menceritakan kepada kami Shadaqah, telah mengabarkan kepada kami Ibnu 'Uyainah, telah mengabarkan kepada kami Ibn Abi Najih dari 'Abdullah bin Katsir dari Abu al-Minhal dari Ibn 'Abbas ra, ia berkata: Ketika Rasulullah saw tiba di Madinah, mereka (penduduk Madinah) mempraktikkan jual beli buah-buahan dengan sistim salaf, yaitu membayar di muka dan diterima barangnya setelah kurun waktu dua atau tiga tahun kemudian beliau bersabda: Siapa yang mempraktikkan salaf dalam jual beli buah-buahan hendaklah dilakukannya dengan takaran yang diketahui dan timbangan yang diketahui, serta sampai waktu yang diketahui." (HR. al- Bukhari, nomor 2086).

Terdapat persoalan lain dalam jual beli salam yaitu jual beli tsamar (buah-buahan) bisa dipahami secara umum meliputi semua hasil komoditas

${ }^{14}$ Ibn Rusyd, Bidāyah al-Mujtabid, hlm. 108 
pertanian. Lebih jauh secara hukum progresif dan modern meliputi perdagangan logam, metal dan komoditas lain termasuk modal.

Ketiga, model BBA secara legal normatif merujuk pada riwayat hadis sebagai berikut:

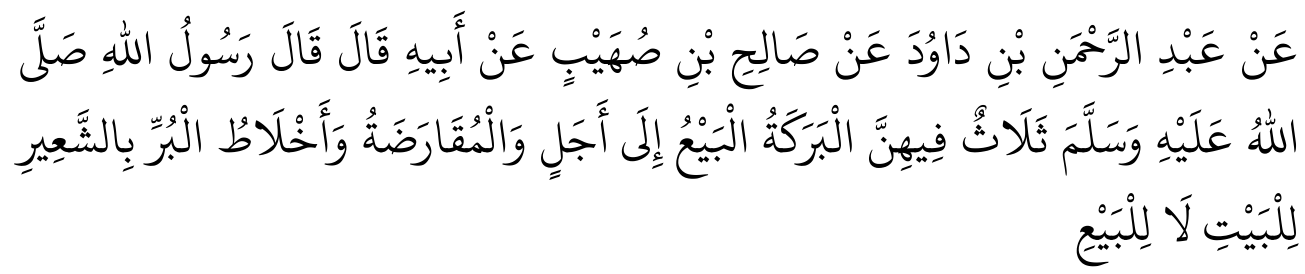

"Dari Abdurrahman bin Daud dari Shalih bin Shuhaib dari ayahnya, dia berkata bahwa Rasulullah saw bersabda: Tiga (hal) yang di dalamnya mengandung keberkahan, yaitu jual beli dengan bayar tunda (angsur), muqäradhah (mudhärabah) dan mencampur gandum (kualitas baik) dengan jelai (gandum kualitas buruk) untuk keperluan keluarga bukan untuk dijual" (HR. Ibn Majah, nomor 2280).

Hadis tersebut menyatakan secara tegas bahwa jual beli dengan bayar angsur merupakan berkah bagi manusia. BBA dalam praktiknya bisa dipahami secara sederhana. Misalnya, seorang menjual gandum seharga 50 real dengan cara bayar angsur selama 4 kali dalam satu bulan, hingga setiap minggu pembeli membayar 12.5 real x $4=50$ real.

BBA dalam praktik bisnis keuangan syariah secara sederhana mirip dengan jual beli (Jawa: mindreng), yakni membeli barang dengan cara pembayaran angsur-kredit, dan menurut pernyataan riwayat bentuk jual beli tersebut mengandung berkah. Meskipun pembayaran dalam BBA secara angsur, tetapi logika ekonomi akan mendesain harga lebih tinggi di atas harga pasar. Secara tidak langsung hadis tersebut mentolerir adanya prinsip time value of money, karena tinggi rendahnya harga barang diperhitungkan dengan waktu pembayaran. Dan masih banyak lagi dasar normatif praktik Rasululllah saw dalam mempertimbangan prinsip time value of money yang jarang dibahas dalam kajian ilmu ekonomi Islam.

Keempat, jual beli 'arayal'arayah. Transaksi 'araya atau 'arayah adalah model jual beli antara pemilik kurma yang masih ada di tangkainya (balah- 
kurma muda) ditukar dengan kurma sudah masak (kering), sebagaimana dinyatakan dalam hadis berikut ini:

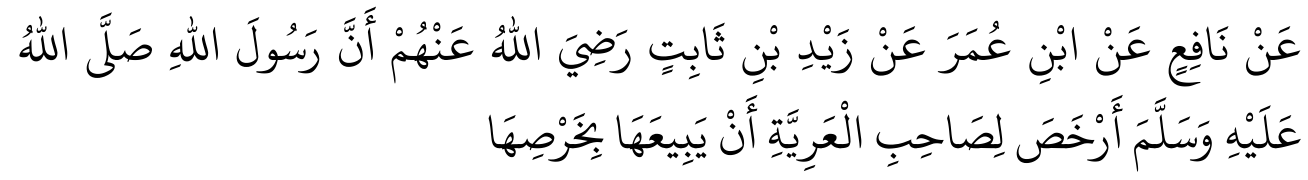

“Dari Nafi' dari Ibn Umar dari Zaid bin Tsabit bahwa Rasulullah saw telah membolehkan jual beli 'ariyyah yaitu menjual kurma beserta tangkainya.” (HR. al-Bukhari, nomor 2039)

Menurut penjelasan imam al-Shan'ani dalam kitab Subul al-Salàm yang dimaksud jual beli 'araya dicontohkan dengan seseorang menjual kurma yang masih di tangkainya ditukar dengan kurma kering (matang) karena alasan kebutuhan keluarga yang mendesak. ${ }^{15}$ Riwayat tersebut dapat dipahami bahwa kurma yang belum masak (balah) boleh ditukar dengan kurma yang sudah masak dengan nilai perbandingan harga yang tentu berbeda. Balah dijual sebelum masa petik misalnya masih kurang enam bulan, tetapi karena kebutuhan keluarga balah dijual dengan penggantian (sebagai alat tukar) berupa kurma kering yang sudah masak dengan masa tanam yang lebih lama daripada balah. Praktik jual beli balah dengan kurma masak ('araya) dibolehkan oleh Nabi saw, di mana balab dengan waktu tanam lebih pendek dapat ditukar dengan kurma masak, sedangkan bentuk jual beli 'araya terkandung perbedaan lamanya waktu diberikan kompensasi, sehingga waktu dalam 'araya memperoleh penghargaan (nilai). Logika ekonomi terhadap pemanfaatan nilai suatu barang atau manfaat dihargai dengan uang atau sebaliknya uang dihargai karena telah memberi manfaat seseorang ternyata terjadi di zaman Nabi saw.

Kasus jual beli 'araya bisa diperbandingkan dengan kasus Bilal menjual kurma dengan kualitas jelek ditukar dengan kurma berkualitas baik, kemudian Rasulullah saw melarangnya. Pada konteks kasus Bilal, jika dipahami dengan pendekatan 'illat (alasan hukum), kurma jelek ditukar dengan kurma baik akan dikhawatirkan terjadi kekecewaan terhadap barang yang diperdagangkan. Oleh karena itu maka jual beli tersebut dilarang, sedangkan dalam kasus 'araya, diperbolehkan jual beli kurma yang masih ada tangkainya (balab)

15 Al-Shan'ani, Subul al-Salām, Juz IV, Singapura: Maktabah al-'Ilmiyah, t.t., hlm. 17. 
ditukar dengan kurma yang sudah masak (kering), karena alasan adanya hajat atau keperluan masyarakat, sehingga pertimbangan unsur riba dikesampingkan. Bahkan saat ini, balah termasuk kurma yang digemari oleh masyarakat Qatar, bukan karena jelek kualitas kurmanya, tetapi menurut perspektif kesehatan, balah memiliki kandungan berupa zat untuk menghaluskan kulit. ${ }^{16}$

\section{Solusi Menghindari Inkonsistensi Prinsip Time Value of Money Sistem Penghitungan pada Transaksi Keuangan di LKS}

1. Qiyas sebagai dasar pengabsahan time value of money

Qiyas dalam perspektif hukum Islam dipahami sebagai alat atau kaidah untuk menetapkan suatu hukum yang terjadi terhadap kasus-kasus baru yang belum ada hukumnya baik dalam al-Qur'an maupun hadis. Ulama ushul fikih menetapkan qiyas sebagai sumber hukum Islam dengan cara-cara sebagai berikut:

Rukun qiyas ada empat, ${ }^{17}$ yaitu: (1) Ashl, yaitu wadah hukum yang ditetapkan melalui nash atau ijma, (2) Far $u$, yaitu kasus yang akan ditentukan hukumnya yang tidak ada hukumnya dalam nas, (3) Hukum ashl adalah hukum syara yang ditentukan oleh nash atau ijma yang akan diberlakukan hukumnya kepada far'u (kasus), dan (4) 'Illat adalah sifat yang menjadi motif dalam menentukan hukum.

Dalam kasus transaksi salam, maka ashl hukum salam pada komoditas pertanian atau perkebunan (yang memiliki sifat mäliyah) adalah boleh. Akan tetapi untuk saat ini objeknya bukan komoditas pertanian/perkebunan, tetapi metal, emas atau uang logam atau uang kertas adalah juga termasuk benda yang memiliki sifat mäliyah, sehingga berdasarkan hukum analogi/qiyas, maka objek akad salam pada jenis benda yang mengandung mäliyah (bernilai), hukumnya pun disamakan dengan komoditas pertanian/perkebunan.

16 Pengalaman penulis selama satu bulan di Qatar (25 Agustus-25 September 2015) dalam rangka visiting profesor kerjasama antara UIN Walisongo dengan Perguruan Tinggi Hammad bin Khalifa), balah menjadi trend bagi masyarakat Qatar untuk dijajakan sebagai salah satu menu buah kurma yang lebih mahal harganya daripada kurma yang sudah masak.

${ }^{17}$ Nasrun Haroen, Ushul Fiqh, Jakarta: Logos Wacana Ilmu,1997, hlm. 63. 
Bahkan sifat mäliyah daripada uang tidak rusak hanya kemungkinan terjadi inflasi, nilai uang akan berkurang. Risiko kehilangan objek salam pada komoditas pertanian/perkebunan jauh lebih besar daripada risiko kerusakan pada metal, logam maupun uang.

Model ijtihad MUI dalam mengharamkan bunga, tidak tegak lurus ketika memposisikan uang kertas sebagai harta ribawi, sehingga nampak tidak konsisten terhadap beberapa keputusan fatwanya. Contoh kasat mata tentang bunga haram, tetapi tetap saja menggunakan sistem operasional versi LKK (Lembaga Keuangan Konvensional), sehingga sampai batas kapan pembungaan uang terjadi di LKS jika tidak mampu mengganti sistem operasional keuangan syariah secara mandiri. Atau pendekatan ijtihad hukum, setidaknya bunga sebagai larangan (makrüh tanzīh) selama belum ada sistem pengganti yang lebih shärih (clear) dan mundhabit (akurat). Hal ini mengacu pada kaidah al-dharürät tubìhu al-mahdlürät (Darurat (hal yang mendesak) membolehkan sesuatu yang dilarang).

Pertimbangan lain, karena selama ini sistem operasional produk transaksi di bank syariah masih blunder dan ambigu, sehingga untuk menghilangkan hukum manipulasi lebih didahulukan daripada menghukumi bunga haram, atau dengan mengedepankan kaidah mengambil perkara yang lebih ringan bahayanya, yakni merevisi keputusan fatwa bunga haram lebih terhormat daripada memanipulasi bentuk transaksi syariah yang sejatinya tidak syariah.

2. Pergeseran paradigma pemikiran konsep mäl/harta

Konsep mäl/harta perspektif ulama fikih terbagi menjadi mäl (harta) mädiyah atau bersifat konkrit dan kasat mata dan mäl manfa'ah atau tidak dapat dilihat oleh mata. Perbedaan antara benda konkrit (mädiyah) dengan manfaat terletak pada sifat bendanya. Meskipun demikian, keduanya sama-sama memiliki nilai kehartaan (mäliyab) yang harus dihargai. Hal ini dapat diilustrasikan ketika manfaat benda milik seseorang dirampas oleh orang lain, maka perampas harus mengembalikan benda yang dirampas. Jika barang yang dirampas berupa manfaat, maka harus mengganti nilai manfaat yang 
dirampas, karena manfaat termasuk harta bernilai sebagaimana yang tersirat dalam ayat al-Qur'an:

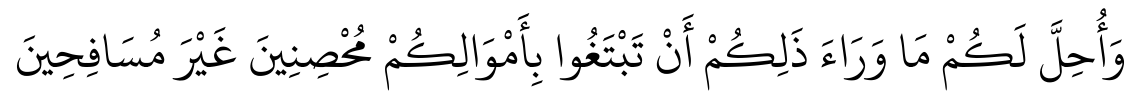

".....dan dihalalkan bagi kalian selain yang demikian itu, (yaitu) mencari istri-istri dengan harta-hartamu untuk dinikahi dan bukan untuk berbuat zina...." (QS. al-Nisa' [4]:24).

Kata amwāl atau harta dalam ayat di atas menurut kesepakatan para fukaha termasuk harta benda bersifat materi dan juga immateri serta dapat diterima sebagai mahar pernikahan, sehingga fungsi manfaat tersebut tidak berbeda dengan harta yang lain. ${ }^{18}$ Dengan demikian maka uang yang digunakan sebagai usaha (modal) oleh orang lain, layak diberikan kompensasi, sehingga antara qardh, yaitu peminjaman uang untuk keperluan konsumtif dan mendasak bukan untuk bisnis, akan berbeda dengan peminjaman produktif, sehingga perlakukan hukumnya pun juga harus dibedakan.

3. Qardh quot and quot modal

Sebagaimana telah disinggung pada uraian di atas bahwa qardh dengan qirädh meskipun dua istilah tersebut berasal dari satu kata qaradha (utang), tetapi dalam perspektif fikih muamalah kedua istilah tersebut secara teknis memiliki pengertian yang berbeda. Qardh dipakai sebagai bentuk transaksi utang piutang uang, sedangkan qiradh identik mudhärabah yaitu kerjasama antara pemilik modal dengan pengelola.

Pada qardh, peminjaman uang bukan sebagai modal untuk dikembangkan atau dipakai usaha dagang, tetapi semata-mata memenuhi kebutuhan primer manusia yang mengalami kesulitan hidup, sehingga konteks pelarangan riba diarahkan pada anjuran untuk bersedekah dan memberi keringanan sampai peminjam memperoleh kemudahan. Hal ini dapat ditangkap dari pembicaraan ayat larangan riba dalam al-Qur'an:

18 Para fukaha empat mazhab (Hanafi, Maliki, Syafi'i dan Hanbali) menurut al-Jazairi (IV: 256) sepakat bahwa manfaat benda bisa dipakai sebagai mahar pernikahan. Lihat juga Mujibatun, Konsep..., hlm. 362. 


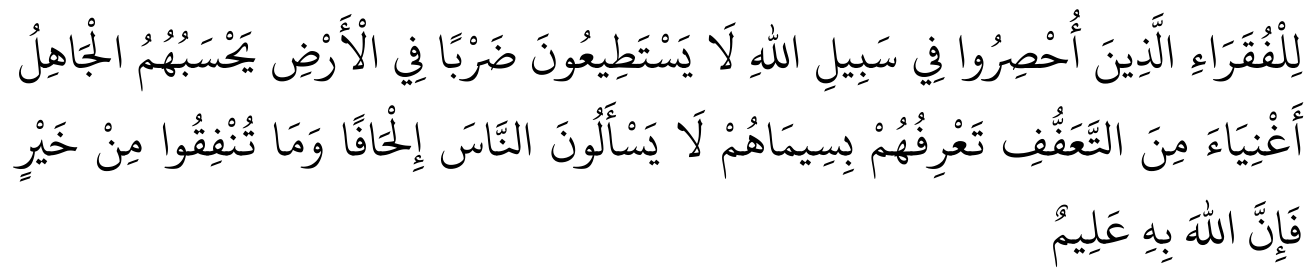

"(Berinfaklah) kepada orang-orang fakir yang terikat (oleh jihad) di jalan Allah, mereka tidak dapat (berusaha) di bumi, orang yang tidak tahu menyangka mereka orang kaya karena memelihara diri dari minta-minta, kamu kenal mereka dengan melihat sifat-sifatnya, mereka tidak meminta orang secara mendesak. Dan apa saja harta yang baik yang kalian nafkahkan (di jalan Allah), maka sesungguhnya Allah Maha Mengetahui (QS. al- Baqarah [2]:273)

Kemudian disusul dengan ayat yang secara tegas menyatakan:

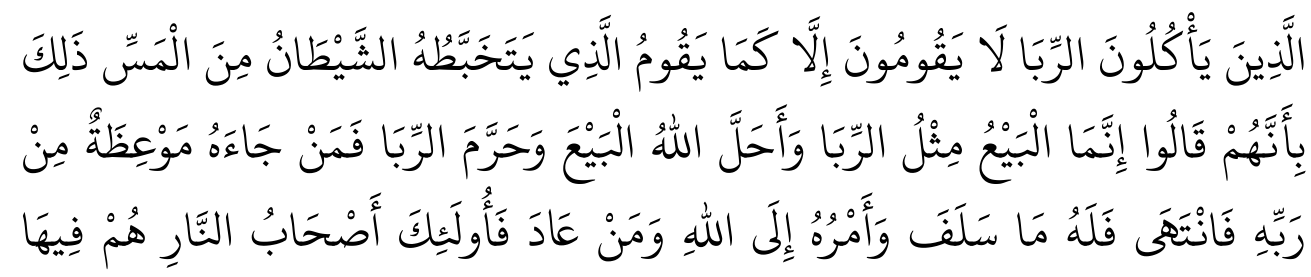

خَالِِدُونَ

"Orang-orang yang makan (mengambil) riba tidak dapat berdiri melainkan seperti berdirinya orang yang kemasukan setan lantaran (tekanan) penyakit gila. Keadaan mereka yang demikian itu, adalah disebabkan mereka berkata (berpendapat), sesungguhnya jual beli itu sama dengan riba, padahal Allah telah menghalalkan jual beli dan mengharamkan riba. Orang-orang yang telah sampai kepadanya larangan dari Tuhannya, lalu terus berhenti (dari mengambil riba), maka baginya apa yang telah diambilnya dahulu (sebelum datang larangan); dan urusannya (terserah) kepada Allah. Orang yang mengulangi (mengambil riba), maka orang itu adalah penghuni-penghuni neraka; mereka kekal di dalamnya." (QS. al-Baqarah [2]:275)

Ayat tersebut secara tegas mengecam orang-orang yang suka mengeksploitasi saudaranya yang miskin dengan mengambil riba bagai orang kemasukan setan karena rakusnya dalam mengambil harta orang lain dan menyamakannya dengan jual beli. Adapun sasaran mereka adalah orang-orang 
mengalami kesulitan yang seharusnya mendapatkan bantuan sedekah, sebagaimana dijelaskan dalam ayat lanjutannya:

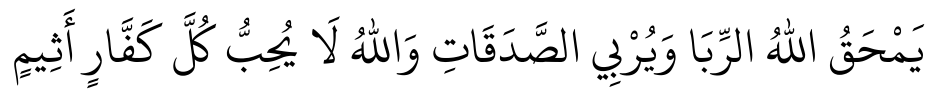

"Allah memusnahkan riba dan menyuburkan sedekah. Dan Allah tidak menyukai setiap orang yang tetap dalam kekafiran, dan selalu berbuat dosa" (QS. al-Baqarah [2]:276)

Kemudian ayat selanjutnya menegaskan:

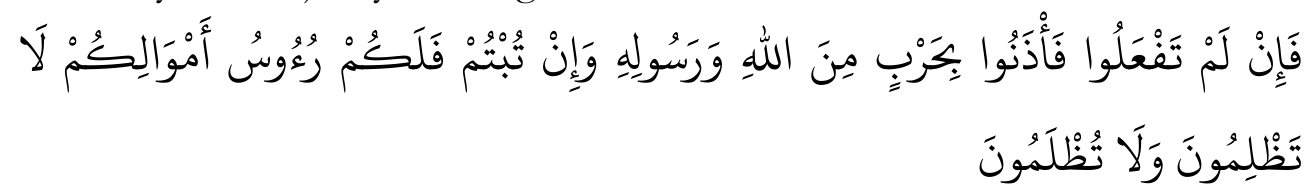

"Maka jika kalian tidak mengerjakan (meninggalkan sisa riba), maka ketahuilah, bahwa Allah dan Rasul-Nya akan memerangimu. Dan jika kalian bertaubat (dari pengambilan riba), maka bagimu pokok hartamu; kalian tidak menganiaya dan tidak (pula) dianiaya." (QS. al-Baqarah [2]:279)

Ayat tersebut menyinggung terhadap orang yang memungut riba (kreditur), jadi bukan orang yang meminjam uang (debitur), sehingga nampak jelas bahwa kecaman riba ditujukan kepada kreditur yang sengaja memanfaatkan kesulitan debitur untuk membayar sejumlah tambahan utangnya, sehingga debitur tidak mampu membayar kecuali dengan menyerahkan apa yang dimiliki misalnya berupa tanah/ kebun. Bahkan dirinya sendiri sebagai tenaga yang dpekerjakan sebagai kompensasi pembayaran utang kepada kreditur sebagaiman digambarkan pada ayat berikutnya:

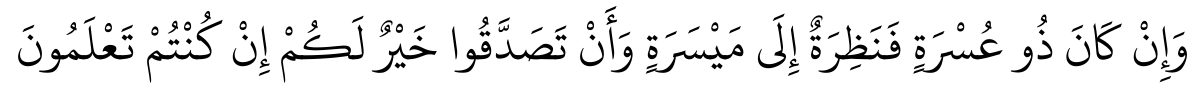

"Dan jika (orang berhutang itu) dalam kesukaran, maka berilah tangguh sampai dia berkelapangan. Dan menyedekahkan (sebagian atau semua utang) itu, lebih baik bagimu, jika kalian mengetahui." (QS. al-Baqarah [2]:280)

Rangkaian ayat-ayat dari surah al-Baqarah mulai ayat 275-280 menegaskan bahwa pungutan tambahan dari sejumlah utang dari orang-orang miskin merupakan kezaliman, seharusnya mereka memperoleh sedekah, 
justru dimintai tambahan dalam mengembalikan utangnya. Sehingga perkataan Ibn Abbas yang menyatakan bahwa "Setiap pinjaman dengan menarik manfaat adalah riba" maksudnya adalah qardh dalam pengertian pinjaman konsumtif dan tidak dipakai sebagai modal usaha.

Berdasarkan informasi dari ayat-ayat tersebut, maka makna qardh secara teknis dimaksudkan untuk akad utang piutang dengan sasaran orang miskin atau mustahik yang seharusnya wajib dibantu. Jika terjadi pungutan tambahan dari utang pokoknya, sekecil apa pun, maka itulah yang dimaksudkan dengan riba yang dikecam oleh Allah dan Rasul-Nya.

Lain halnya dengan qirädh (mudhärabah) secara teknis dimaksudkan adalah memutar modal (uang) untuk dikembangkan sehingga hampir dipastikan dengan akad qirädh, akan didapatkan keuntungan, sehingga keuntungannya bisa dibagi dengan parter bisnisnya, yakni pemilik modal. Lebih-lebih pemilik modal tidak ahli dalam urusan bisnis, maka tepat kiranya pengelola uang (modal) adalah seorang ahli dalam bidang bisnis, sedangkan pemilik modal tidak ahli berbisnis. Dengan kerjasama antara kedua pihak, tercipta simbiosis-mutualisme. Inilah yang dimaksud dengan hadis Nabi saw tentang 3 hal yang mengandung berkah salah satunya yaitu bentuk transaksi muqāradhah atau mudhārabah.

\section{Koherensi dan Korespondensi dalam Metode Pemahaman Teks (Hadis)}

Menurut Amin Abdullah19 bangunan konstruksi dasar pemikiran ilmu keislaman untuk saat ini dirasa penting untuk diuji ulang validitasnya lewat cara berfikir konsisten, koheren dan koresponden oleh kelompok ilmuan sejenis, dengan berbagai pertimbangan antara lain:

Pertama, dalam rangka menjaga gesekan antar internal umat Islam dan juga antara sesama umat beragama yang berbeda. Di dunia ini terdapat banyak living religion yang memiliki sistem tata pikir dan seperangkat nilai dan keyakinan sama sebagaimana yang dipraktikkan oleh umat Islam, meskipun berbeda kitab suci, Nabi, bahasa yang dijadikan tokoh karismatik dan $74-80$.

19 Amin Abdullah, Islamic Studies di Perguruan Tinggi, Yogyakarta: Pustaka Pelajar, 2006, hlm. 
panutannya, tata cara ritual peribadatan serta letak geografis para pemeluknya yang berbeda.

Kedua, semakin dekatnya hubungan kontak individu maupun sosial antara berbagai etnik, ras, suku dan agama sebagai akibat teknologi, transformasi, komunikasi dan informasi canggih

Ketiga, tingginya intensitas konflik internal umat Islam sering dipicu oleh pembenaran satu ideology komunitas tertentu yang saling berseberangan dengan ideology komunitas lain, hingga terjadi saling hujat, saling sesat bahkan saling mengkafirkan.

Dalam upaya mengeliminir konflik, pemahaman teks wahyu (al-Qur'an dan hadis), menurut Amin ${ }^{20}$, terdapat tiga pilar utama untuk mencermati bagaimana agar teks (dalam hal ini) riwayat atau hadis tentang konsep time value of money tidak rancu atau tumpang tindih antara satu dengan yang lain, sehingga secara logis konsep tersebut bisa dicermati dengan mengacu pada tiga aspek yaitu:

1. Konsistensi, yang berasal dari bahas latin consistere, artinya "berdiri bersama", harmoni, sesuai". Menurut istilah teknik filsafat, konsistensi artinya hubungan logis. Misalnya, ajaran tentang menghargai kemanusian memiliki hubungan terpadu dengan ajaran tentang lemah lembut atau teks al-Qur'an memiliki hubungan dengan teks hadis (munāsabah al-ayàt).

2. Koherensi, yang berasal dari bahasa latin cohaerere, artinya "lekat satu dengan lainnya”. Maksudnya bahwa satu konsep ajaran (Islam) yang satu harus terkait dengan konsep ajaran yang lain, tidak boleh terlepas sendiri sendiri. Konsep ketuhanan harus berhubungan dengan konsep kepedulian sosial, doktrin ukhuwah harus bersambung dengan dengan yang bersifat islamiyah, atau diniyah bersambung dengan basyariyah, begitu seterusnya. Seorang muslim, pejabat muslim tetapi masih juga melakukan korupsi. Begitu juga dalam operasional bank syariah yang non bunga, tetapi secara faktual masih memakai penghitungn sistem operasional bank berbunga.

${ }^{20} \mathrm{Ibid}$, hlm. 79-80. 
3. Korespondensi, yang berasal dari dua kata latin; yaitu co yang artinya "bersama" dan respondere yang artinya "bertanggung jawab". Korespondensi maksudnya antara teori dengan praktik, antara konsep murni dengan terapan harus sama. Hal ini dapat dicermati misalnya di Indonesia, banyak penduduk muslim tetapi prilakunya tidak mencerminkan ajaran Islam yang sesungguhnya.

Demikian juga konsep time value of money yang ditolak oleh pakar perbankan syariah, ternyata secara praktikal penghitungan sistem operasional bank syariah masih terjebak pada pemberlakuan konsep time value of money yang dianggap riba.

\section{Kesimpulan}

Dari penelitian ini dihasilkan kesimpulan sebagai berikut:

1. Time value of money dalam ideologi penghitungan sistem keungan syariah tidak diterima, karena bertambahnya nilai uang sebagai harta kekayaan diperoleh harus dari perputaran uang dengan usaha seseorang secara riil (bisnis), bukan berasal dari pendapatan pertambahan uang karena akad utang/ qardh.

2. Time value of money menurut konsep ekonomi Rasulullah saw dapat dicermati pada berbagai bentuk transaksi yang dilegalkan melalui beberapa riwayat seperti salam, jual beli dengan bayar angsur (BBA) dan 'araya serta pengabsahan pemberian diskonto karena penyegeraan pembayaran utang.

3. Prinsip time value of money yang dianggap riba dalam praktik bisnis LKS baik melalui pendekatan qiyas maupun berdasar pada riwayat, terbukti tidak konsisten dan tidak sejalan dengan praktik bisnis Rasulullah saw, kecuali diberlakukan hanya pada LKS non-bank (sektor riil), karena selama ini penghitungan sistem operasional perbankan syariah masih menggunakan acuan suku bunga dan cara menghitungnya pun masih berbasis pada sistem perbankan dengan sistem bunga.

Dari hasil penelitian ini ada beberapa rekomendasi dan saran yang perlu diperhatikan, yaitu: 
1. Perlakuan uang sebagai modal komoditas dalam sistem perbankan syariah terus berjalan sehingga uang beranak uang (bunga) sulit dihindarkan dalam sistem operasionalnya. Untuk itu, jika perbankan syariah tetap konsisten mengusung ideologi bunga haram, maka perlu dilakukan terobosan fundamental dalam membuat sistem operasional bank syariah sesuai dengan jati diri kesyariahannya. Keterlibatan institusi akademik menjadi keniscayaan dalam memunculkan ilmu baru guna mempertahankan ideologi itu. sebelum terwujudnya ideologi tersebut, sementara Komisi Fatwa DSN-MUI sebagai rujukan sistem operasional LKS di Indonesia perlu mengeluarkan produk fatwa berupa kaidah/prinsip "(Keadan) darurat membolehkan hal yang dilarang”.

2. Pengelola LKS perlu menggalakkan produk BBA (Bai’ Bitsaman Ajī), sebagaimana model jual beli mindreng sesuai dengan tradisi dan kearifan lokal sebagaiamana yang berjalan di tengah-tengah masyarakat Jawa selama ini. Dengan mengedepankan sifat ta'äwun (kebersamaan), akan meningkatkan ekspektasi kerjasama dalam rangka mewujudkan kesejahteraan ekonomi umat sebagaimana yang dicita-citakan kita bersama. 
Inkonsistensi Prinsip Time Value of Money...

\section{DAFTAR PUSTAKA}

Abdullah, Amin, Islamic Studies di Pergurun Tinggi, Yogyakarta: Pustaka Pelajar, 2006.

CD-ROM, Mausu'ah al- Hadis al-Syarif Kutub al- Tis'ah, Edisi II Tahun 1997.

Haroen, Nasrun, Ushul Fiqh, Jakarta: Logos Wacana Ilmu,1997.

Jazzar (al), Ja'far, al-Bunūk fi al-'Alam: Anwāuhà wa Kaifa Tata'ämalu Ma'ahā, Beirut: Dār al-Nafāis, 1984.

Masyhuri dkk, Teori Ekonomi dalam Islam, Yogyakarta: Kreasi Wacana, 2005.

Mujibatun, Siti, Konsep Uang dalam Hadis, Semarang: ELsA, 2013.

--------, Hasil Penelitian Qatar 2015, Semarang: LP2M UIN Walisongo, 2015.

Naqvi, Syed Nawab Haedar, Menggagas Ilmu Ekonomi Islam, terj. M. Saiful Anam \& Muhammad Ufuqul Mubin, Yogyakarta: Pustaka Pelajar, 2005.

Rusyd, Ibn, Bidāyah al-Mujtahid, Juz 2, Beirut: Dār al-Fikr, t.t.

Saidi, Zaim, Tidak Islaminya Bank Islam, Jakarta: Ekonesia, 2003.

Shan'ani (al), Subul al-Salam, Juz IV, Singapura: Maktabah al-'Ilmiyah, t.t.

Shihab, Quraish, Riba dalam Al-Qur'an, Jakarta: Hikmah Syahid, 2006.

Vogel, Frank.E, dan Samuel L. Hayes, Hukum Keuangan Islam: Kinsey, Teori dan Praktik, terj. M. Sobirin Asnawi dkk, Bandung: Nusamedia, 2007. 